after 14 days it had fallen to $60 \%$ with $10 \%$ of reticulocytes in the peripheral blood. Then the S.G.O.T. was 57 units ; S.G.P.T. 44 units; total serum bilirubin $2.9 \mathrm{mg} . / 100 \mathrm{ml}$.; conjugated bilirubin $2.3 \mathrm{mg} . / 100 \mathrm{ml}$. The urine and faeces were returning to normal colour, the urine containing a marked excess of urobilinogen. 24 days after admission the $\mathrm{Hb}$ was $68 \%$; reticulocytes $10 \%$; E.S.R. $127 \mathrm{~mm}$. in 1 hour; S.G.O.T. 60 units; S.G.P.T. 50 units.

As the infection cleared the jaundice faded, the liver tenderness subsided, and the patient subsequently made an uninterrupted recovery, with return of $\mathrm{Hb}$ to normal $(97 \%)$.

Appropriate tests were performed to exclude sickle-cell anaemia, glucose-6-phosphate dehydrogenase deficiency, virus infection, including psittacosis and Eaton agent pneumonia, and systemic lupus. Direct Coombs test was negative.

Although cholestasis was undoubtedly present in this patient, the degree of haemolysis and liver-cell damage appeared to be much greater than could be accounted for by the consequences of intrahepatic cholestasis itself, although presumably the cause of the haemolysis and cell damage was basically the same as that of the cholestasis. The precise mechanism by which these occurred, as in the cases of Eley and his colleagues, is not clear, but a circulating toxin, presumably bacterial in origin, was probably responsible, affecting the cells of the excretory pathway, the liver cells, and the circulating red cells. -We are, etc.,

A. Gordon Beckett.

New End Hospital

J. D. WARD.

London N.W.3.

\section{Injured Baby}

SIR,-Dr. Patricia A. Russell's excellent review of 25 cases of infantile subdural haematoma (21 August, p. 446) shows birth trauma is no longer the only, or indeed commonest, aetiological cause. It appears that nowadays post-natal trauma, including deliberate injuries, accounts for three times as many cases as birth trauma. The importance of this was brought home to me quite recently.

A male child aged 3 weeks was admitted to the Torbay Hospital with a week's history of excessive irritability, jerky movements of the hands, and lethargy. The right eye was noted to be closed for four days and he had refused feeds over the same period. On admission he looked ill and marasmic. He had a paresis of the right upper lid, twitching of the left eye, and neck stiffness. The fontanelle was tense and there was a retinal haemorrhage on the right side. He was found to have subdural collections of fluid on both sides, with a larger collection on the left. He was treated with repeated aspirations initially at the Torbay Hospital and later in the neurosurgical unit at Bristol. Nn surgical treatment was necessary. After discharge he was found to have a mild left-sided hemiparesis for which he received physiotherapy.

In July 1965, when the patient was 6 months old, the physiotherapist noticed painful swellings of the right arm and leg, and signs of bruising. Treatment was discontinued and the child referred back to the clinic. By then the right arm was improved, but now the left upper arm was swollen and tender. $X$-rays of the 1 ng bones showed oblique fractures of both humeri, periosteal reaction alnng the medial sides of the shafts of both femora, and a deformity at the upper end of the right tibia. The appearances were thought to be compatible with multiple trauma. On intervlewing the mother it seemed difficult to believe that anything other than loving care and kindness had ever been shown towards the infant. The general practitioner and health visitor alike expressed their amazement at the diagnosis.

It is well known that the syndrome of multiple epiphysial injuries is often unsuspected. Subdural haematoma in an infan may well be the first indication of this, and careful surveillance of families in whom a case has occurred is advisable. This must include the watching of subsequent siblings. -I am, etc.,

Torbay Hospital,
Torquay, Devon.

L. HaAs.

\section{Amenorrhoea}

SIR,-Professor T. N. A. Jeffcoate's article (14 August, p. 383) is very interresting and informative and quite properly emphasizes the importance of fully investigating patients with primary amenorrhoea. It is also right to refer to the need to investigate " certain cases" of secondary amenorrhoea, but the statement that " not less than $60 \%$ of cases" of secondary amenorrhoea are accounted for by "psychological and environmental" factors may be misleading, since it implies that some $40 \%$ of women with secondary amenorrhoea have causes other than psychological or environmental factors. Although this might be so among women attending hospital gynaecological out-patient clinics (although I doubt it), it is certainly nothing like this incidence in women seen in general practice.

The figures comprising the accompanying table are taken from several studies in my practice and show, as Professor Jeffcoate states, that the commonest cause of secondary amenorrhoea is pregnancy. In my experience, the next commonest cause is a mixture of fear that pregnancy may have occurred and the guilt so often associated with promiscuous sexual intercourse. Although it is true that change of environment for a young woman may be followed by a period of amenorrhoea, it does not follow that the relevant factor is an environmental one. In fact, the statement in your leader (14 August, p. 380) that "Professor Jeffcoate concludes that, apart from pregnancy, environmental and psychological causes underlie more than $60 \%$ of cases of secondary amenorrhoea," also tends to mislead the reader by perpetutating the myth that environmental factors are relevant when it is so often the effect of the environmental change on the woman's (or girl's) psychological or emotional state that is important.

\begin{tabular}{|c|c|c|c|}
\hline \multirow{3}{*}{ Year of Study } & \multicolumn{3}{|c|}{ Amenorrhoea } \\
\hline & \multirow{2}{*}{ Primary } & \multicolumn{2}{|c|}{ Secondary } \\
\hline & & $\begin{array}{l}\text { Preg- } \\
\text { nancy }\end{array}$ & $\begin{array}{l}\text { Psycho- } \\
\text { logical }\end{array}$ \\
\hline 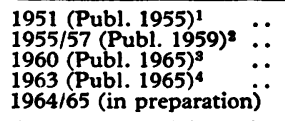 & $\begin{array}{l}\overline{1} \\
1 \\
1\end{array}$ & $\begin{array}{l}22 \\
57 \\
24 \\
31 \\
34\end{array}$ & $\begin{array}{l}11 \\
19 \\
13 \\
12 \\
15\end{array}$ \\
\hline Totals $\quad .$. & 3 & 168 & 70 \\
\hline
\end{tabular}

Professor Jeffcoate's statement that: ".... whatever be the nature of the treatment given there is a $60 \%$ chance of cure in cases of secondary amenorrhoea of more than one year's duration. In most cases this cure is spontaneous ..." regrettably does nothing to make it more widely known that many more of these very anxious ladies could be helped very much more by formal psychotherapy, often of quite a superficial level, with or without simple sedation according to the general condition of the individual patient.

The ". . . . sympathetic attitude and cheerful encouragement ..." advocated in your leader are surely required by all our patients? But those patients also requiring a surgical operation have this as well. Surely those patients having somatic reactions to psychological or emotional disturbances should also be treated with psychotherapy.

There would be far fewer patients having assays of their urinary excretion of 17-ketosteroids and gonadotrophins, to say nothing of enormous numbers of other complex, expensive, and perhaps unnecessary investigations if we doctors in general practice could only have the time in which to treat our patients as the sick people they are, instead of having to pass them on to hospital as cases of disease for investigation.- I am, etc.,

London N.W.3.

PhILIP Hopkins.

\section{REFERENCES}

1 Hopkins, P., in Modern Trends in Psychosomatic Medicine, 1955, Chapter 1, edited by D. O'Neill. Butterworth, London.

2 7. Col. gen. Practit., 1959, 2, 246

in Psychosomatic Disorders in Adolescents and Young Adults, 1965, edited by J. Hambling and P. Hopkins. Pergamon Press, Oxford.

V in Encyclopaedia of General Practice, 1964, R. M. S. McConaghey. Butterworth, London.

SIR,-I was most interested in Professor T. N. A. Jeffcoate's paper on amenorrhoea (14 August, p. 383). I would like to draw attention to the fact that amenorrhoea, which he found to be such a common symptom of pelvic tuberculosis in the Liverpool area, does not appear to be true for other areas. In 73 consecutive cases diagnosed and treated by me not one case complained of amenorrhoea. In fact, the only menstrual disturbance complained of was menorrhagia, and this in only four patients. I mention this fact only in case anybody might be inclined to dismiss the possibility of pelvic tuberculosis in a patient not complaining of menstrual disturbance, and because somebody might suggest a reason for this variation.-I am, etc.,

Galway, Eire. DiARMuId O'Driscoll.

\section{Umbilical-vein'Exposure for Transfusion in Newborn}

SIR,-It is sometimes necessary to expose: the umbilical vein of newborn infants for transfusions, and this vein is the one most commonly used in exchange transfusion. After about 24 hours the umbilical stump is not serviceable, and a cut-down is necessary.

The procedure for this exposure described in books ${ }^{1}$ involves an incision about $\frac{1}{2}$ in. $(12.7 \mathrm{~mm}$.) above the stump. However, in this position the vein is deeply situated and is already well on its way towards the abdominal cavity. The peritoneum is there- 